\title{
COMBINED LASER TREATMENT OF EARLY IDIOPATHIC EPIRETINAL MEMBRANE: CLINICAL EVALUATION OF THE DEVELOPED TECHNIQUE
}

Takhchidi KP',2, Kachalina $\mathrm{GF}^{2}$, Kasminina $\mathrm{TA}^{2}$, Tebina EP ${ }^{3} \otimes$

${ }^{1}$ Pirogov Russian National Research Medical University, Moscow, Russia

${ }^{2}$ Research Center for Ophthalmology, Pirogov Russian National Research Medical University, Moscow, Russia

${ }^{3}$ Faculty of Pediatrics, Pirogov Russian National Research Medical University, Moscow, Russia

Process of development of epiretinal membrane (ERM) on the retinal surface of macular area is one of the important problems associated with vitreoretinal pathologies. Up to the present day, there has not been developed an effective method to arrest fibrosis at the early stages of its development. This study aimed to evaluate efficacy and safety of the new combined laser technique designed to treat early idiopathic ERM (stages 0-1). Ninety-two patients aged 64.7 \pm 9.6 years (mean) participated in the clinical research. They were divided into three groups: treatment group $(n=32)$, patients whose ERM was treated following the new combined laser technique; comparison group $(n=30)$, patients who underwent grid laser coagulation; control group $(n=30)$, no treatment, observation of the natural course. Based on the results of examination of the patients, we assessed uncorrected visual acuity, best corrected visual acuity, central retinal thickness, central retinal sensitivity. Assessed against the results registered in comparison and control groups, the developed combined laser treatment technique applied in the treatment group proved to be highly effective in maintaining/improving visual functional indicators and stabilizing/improving morphofunctional indicators throughout the entire period of observation. As pertains to the morphological and functional structures of sensory retina, the technique enabled retinal sensitivity improvement at different stages of observation, which reflects its safety and efficacy.

Keywords: idiopathic epiretinal membrane, subthreshold micropulse laser exposure, combined laser technology, optical coherent tomography

Author contribution: Takhchidi KP and Kachalina GF conceived and designed the study; Tebina EP collected and analyzed the data; Kasminina TA performed laser therapy; Kasminina TA, and Tebina EP wrote the manuscript; Takhchidi KP revised the manuscript.

Compliance with ethical standards: the study was approved by Russian National Research Medical University (Protocol № 160 of December 19, 2016).

$\triangle$ Correspondence should be addressed: Ekaterina P. Tebina

Volokolamskoe shosse 30, bld. 2, 123182; ekaterinatebina@mail.ru

Received: 18.03.2019 Accepted: 02.04.2019 Published online: 30.04.2019

DOI: $10.24075 /$ brsmu.2019.033

\section{КЛИНИЧЕСКАЯ ОЦЕНКА РАЗРАБОТАННОЙ ТЕХНОЛОГИИ КОМБИНИРОВАННОГО ЛАЗЕРНОГО ЛЕЧЕНИЯ ПРИ НАЧАЛЬНЫХ СТАДИЯХ ИДИОПАТИЧЕСКОЙ ЭПИРЕТИНАЛЬНОЙ МЕМБРАНЫ}

\author{
Х. П. Тахчиди ${ }^{1,2}$, Г. Ф. Качалина ${ }^{2}$, Т. А. Касмынина², Е. П. Тебина ${ }^{3}$
}

${ }^{1}$ Российский национальный исследовательский медицинский университет имени Н. И. Пирогова, Москва, Россия

2 Научно-исследовательский центр офтальмологии, Российский национальный исследовательский медицинский университет имени Н. И. Пирогова, Москва, Россия

${ }^{3}$ Педиатрический факультет, Российский национальный исследовательский медицинский университет имени Н. И. Пирогова, Москва, Россия

\begin{abstract}
Одной из актуальных проблем витреоретинальной патологии является процесс формирования эпиретинальной мембраны (ЭРМ) на ретинальной поверхности макулярной зоны. До настоящего времени не существует эффективных методов, оказывающих антипролиферативное и антиконстрикторное действие на фиброзный процесс на начальных этапах его развития. Целью исследования являлась оценка эффективности и безопасности технологии комбинированного лазерного лечения пациентов с начальными стадиями (0-1 стадия) идиопатической ЭРМ. В клиническое исследование были включены 92 пациента (64,7 \pm 9,6 лет). Основную группу составили 32 пациента (32 глаза), которым было проведено лазерное лечение по комбинированной технологии. Группу сравнения составили 30 пациентов (30 глаз), лечение которых осуществлялось с применением лазерной коагуляции по типу «решетки». В контрольную группу были включены 30 пациентов (30 глаз), у которых было установлено динамическое наблюдение за естественным течением пролиферативного процесса без лазерного и консервативного лечения. По результатам офтальмологического обследования проводилась оценка некоррегированной остроты зрения, максимально коррегированной остроты зрения, центральной толщины сетчатки и центральной светочувствительности сетчатки. Разработанная технология комбинированного лазерного лечения показала высокую эффективность, заключающуюся в сохранении/увеличении зрительно-функциональных показателей и стабилизации/улучшении морфофункциональных показателей сетчатки в течение всего периода наблюдения. Безопасность и эффективность разработанной лазерной технологии в отношении морфофункциональных структур сенсорной сетчатки отражалась в увеличении показателей светочувствительности сетчатки в различные сроки наблюдения.
\end{abstract}

Ключевые слова: идиопатическая эпиретинальная мембрана, субпороговое микроимпульсное лазерное воздействие, комбинированная лазерная технология, оптическая когерентная томография

Информация о вкладе авторов: Х. П. Тахчиди, Г. Ф. Качалина - концепция и дизайн исследования; Е. П. Тебина - сбор и обработка материала; Т. А. Касмынина - лазерное лечение пациента; Т. А. Касмынина, Е. П. Тебина — написание текста; Х. П. Тахчиди - редактирование.

Соблюдение этических стандартов: исследование одобрено этическим комитетом РНИМУ имени Н. И. Пирогова (протокол № 160 от 19 декабря 2016 г.).

$\triangle$ Для корреспонденции: Екатерина Павловна Тебина

Волоколамское шоссе, д. 30, корп. 2, г. Москва, 123182; ekaterinatebina@mail.ru

Статья получена: 18.03.2019 Статья принята к печати: 02.04.2019 Опубликована онлайн: 30.04.2019

DOI: $10.24075 /$ vrgmu.2019.033

In the recent years, numerous researchers studied the problem of formation of connective tissue in the eye [1-4]. However, there is one special vitreoretinal pathology, macular fibrosis, which causes significant deterioration and even irreversible loss of visual function in working age population.
Despite the considerable progress in understanding etiological, pathological and genetic mechanisms of formation of epiretinal membrane (ERM), some questions pertaining to the development idiopathic ERM remain unanswered [5]. The main factors contributing to the development of this pathology are: 
impaired biomechanical processes at the vitreoretinal interface, namely, posterior vitreous detachment (PVD); micropores in the internal limiting membrane (ILM); pathological changes of the macular microvasculature [6-8]. Regardless of the pathogenetic mechanism of ERM development, migration and proliferation of various cell types play a key role in its formation and progression, the cells being glial cells (Muller retinal cells, astrocytes and microglia), hyalocytes, macrophages, retinal pigment epithelium (RPE) and retinal surface fibroblasts [9, 10]. Influenced by cytokines and growth factors, these cells transdifferentiate into a phenotype similar to myofibroblasts [11]. With aseptic inflammation in the background, myofibroblasts undergo apoptosis [11, 12]. In fibrosis, myofibroblasts activate and, when persisting for a long period of time, cause excessive deposition of collagen followed by its remodeling [13]. Evidence obtained through ophthalmoscope examination [14] and with the help of a number of current fundus pathology investigation methods allows isolating three main stages (grades) of ERM development: stage 0 - cellophane maculopathy, stage 1 crinkled cellophane maculopathy, and stage 2 - macular puckering. Depending on the stage, clinical manifestations of the disease vary from total lack of symptoms to a significant visual function deterioration [15]. To date, there are no safe and effective methods that allow slowing down cell proliferation and progression of fibrosis in its early stages.

Globally, medical researchers and practitioners successfully subject late-stage ERM to vitreoretinal surgery, having accumulated significant related experience. However, despite the positive surgery results, numerous histological studies have shown that ILM peeling damages Muller cells and compromises retina architectonics and biomechanical strength $[16,17]$. As a result, complete restoration of vision after such surgery occurs in $5-25 \%$ of cases only [18]. Moreover, this kind of treatment is prescribed in case the clinical symptoms, i.e. visual function alteration and/or deterioration, are pronounced. Up to the present, the main tactic for managing ERM patients has been dynamic observation [19].

Thus, development of an effective and safe early-stage ERM treatment technique yielding stabilization and/or improvement of vision and functional indicators is an urgent problem.

Given the urgency, such a technique was developed in the Research Center for Ophthalmology of Pirogov Russian National Research Medical University. The technique combines grid laser photocoagulation and exposure to $577 \mathrm{~nm}$ subthreshold micropulse laser light (RF patent №. 2634684, 02.11.2017), the two techniques that differ in their mechanism of action [20]. This study aimed to evaluate efficacy and safety of the combined laser technique designed to treat early idiopathic ERM (stages 0-1).

\section{METHODS}

Ninety-two patients aged $64.7 \pm 9.6$ years (mean) participated in the clinical research. The inclusion criteria were: early idiopathic epiretinal membrane (stage 0-1) with concomitant lens pathology: pseudophakia or early cataract.

All patients were randomized into three groups depending on the treatment tactics. The treatment group included 32 patients (32 eyes); they underwent laser treatment following the combined technique developed at the Research Center for Ophthalmology of Pirogov Russian National Research Medical University. The comparison group consisted of 30 patients (30 eyes); their treatment was laser coagulation, "lattice" type. The control group included 30 patients (30 eyes); they received neither laser nor conservative treatment, and natural proliferation of their fibroses was under dynamic observation.

The new technique is a combination of grid laser photocoagulation and subthreshold micropulse laser irradiation [20]. We used IRIDEX IQ 577 retinal surgery laser (IRIDEX Corporation, Mountain View; USA) that works in continuous and micropulse modes.

Grid laser photocoagulation was the first stage of the treatment. We irradiated the entire surface of ERM except for the avascular zone; the wavelength was $577 \mathrm{~nm}$, power - $50 \mathrm{~mW}$, pulse duration - $0.05 \mathrm{~s}$, spot diameter - $100 \mu \mathrm{m}$, distance between coagulates - $150 \mu \mathrm{m}$. After two weeks, ERM was exposed to subthreshold laser micropulses (second stage of the combined laser treatment technique); the wavelength was $577 \mathrm{~nm}$, pulse packet duration — $30 \mathrm{~ms}$, micropulse duration $50 \mu \mathrm{s}$, pulse ratio $-4.7 \%$, spot diameter $-100 \mu \mathrm{m}$, power $50 \mathrm{~mW}$ (Table 1). Since we registered no significant changes after the 4th session, treatment group patients had only 3 sessions of subthreshold micropulse laser treatment, each a month apart.

All patients underwent standard ophthalmic and special examinations: multispectral with various filters (Blue, Green, Infrared Reflectance, MultiColor), spectral optical coherent tomography (SOCT) «Spectralis OCT» (Heidelberg Engineering, Inc; Germany ) and microperimetry MAIA (CenterVue; Italy).

All participants were examined before treatment and 3 months, 6 months, 1 year, 2 years, 3 years, 4 years and 5 years after treatment. Treatment and comparison group patients also underwent examination after each stage of laser treatment.

Table 1. Protocol of the developed combined laser treatment technique for idiopathic ERM

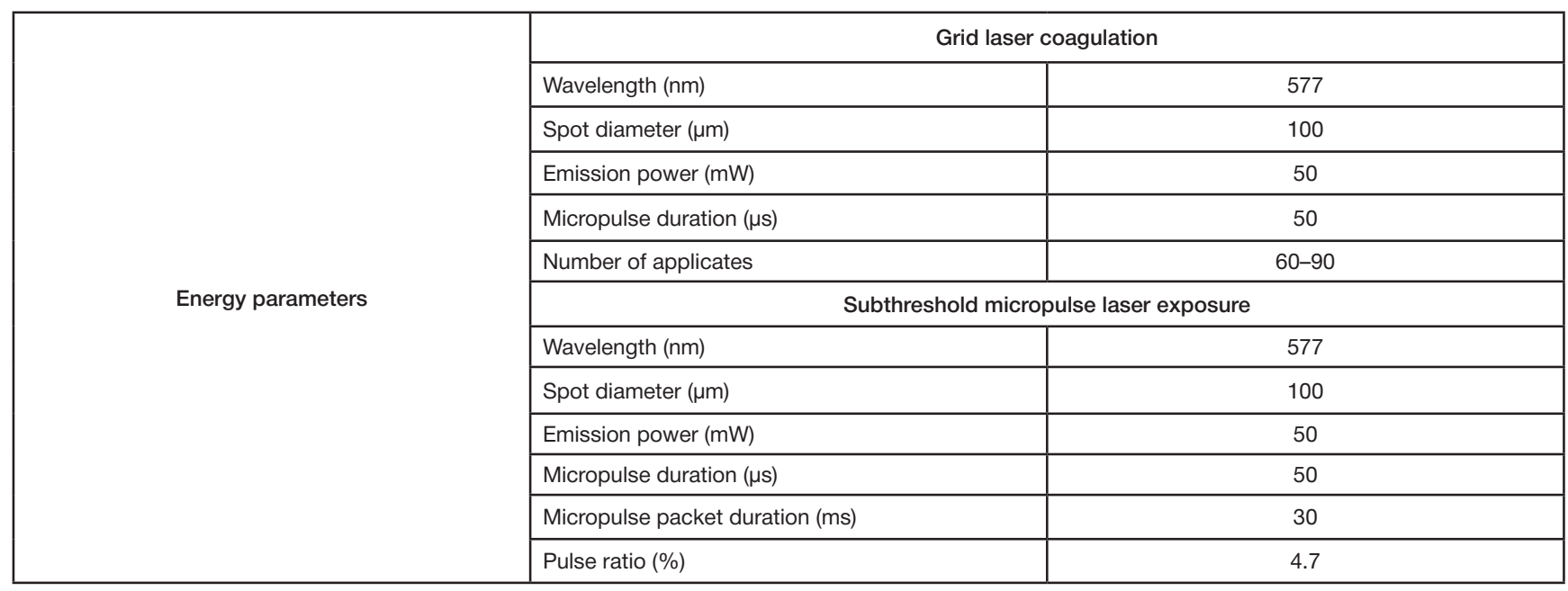


Central retinal sensitivity was used as the basis for clinical assessment of safety of laser treatment.

We assessed uncorrected visual acuity (UVA), best corrected visual acuity (BCVA), central retinal thickness (CRT), central retinal sensitivity (CRS). These indicators were subjected to normal distribution; methods of parametric statistics (paired sample $t$-test) were applied to the data acquired to compare benchmark figures and results of treatment at different observation timepoints. Single-factor analysis of variance (ANOVA) was used to assess the significance of differences in comparison of results from more than two independent groups. The differences were considered statistically significant at $p<0.05$.

Table 2. Clinical and functional results of treatment of patients (clinical groups)
RESULTS

Results of initial examination of patients from the treatment group (32 eyes): UVA $-0.45 \pm 0.31$, BCVA $-0.9 \pm 0.13$, CRS (microperimetry data) $-26.3 \pm 1.65 \mathrm{~dB}, \mathrm{CRT}$ (OCT data, mean) $-282.8 \pm 27.1 \mu \mathrm{m}$.

In the comparison group (30 eyes), the pre-surgery indicators were: UVA $-0.44 \pm 0.26$, BCVA (mean) $-0.86 \pm 0.15$, CRT (mean) $-26.3 \pm 1.57, \mathrm{CRT}$ (mean) $-292.4 \pm 62.2 \mu \mathrm{m}$.

Initial indicators registered in the control group (30 eyes) were as follows: UVA (mean) $-0.64 \pm 0.23$, BCVA $-0.87 \pm 0.14$, CRS (mean, microperimetry data) $-27.1 \pm 1.52 \mathrm{~dB}$, CRT (mean) $301.4 \pm 44.8 \mu \mathrm{m}$.

\begin{tabular}{|c|c|c|c|c|}
\hline Observation period & Treatment group & Comparison group & Control group & ANOVA, $p$ \\
\hline \multicolumn{5}{|c|}{ Mean uncorrected visual acuity } \\
\hline Before treatment & $0.45 \pm 0.31$ & $0.44 \pm 0.26$ & $0.64 \pm 0.23$ & 0.01 \\
\hline 3 months & $0.57 \pm 0.3^{*}$ & $0.47 \pm 0.27^{\star}$ & $0.63 \pm 0.23^{*}$ & 0.08 \\
\hline 6 months & $0.59 \pm 0.31^{*}$ & $0.43 \pm 0.27^{\star}$ & $0.6 \pm 0.24^{*}$ & 0.13 \\
\hline Year 1 & $0.61 \pm 0.31^{*}$ & $0.42 \pm 0.27^{*}$ & $0.56 \pm 0.26^{*}$ & 0.04 \\
\hline Year 2 & $0.61 \pm 0.3^{*}$ & $0.42 \pm 0.27^{\star}$ & $0.53 \pm 0.25^{\star}$ & 0.03 \\
\hline Year 3 & $0.6 \pm 0.3^{*}$ & $0.42 \pm 0.27^{*}$ & $0.48 \pm 0.26^{*}$ & 0.03 \\
\hline Year 4 & $0.61 \pm 0.2^{*}$ & $0.42 \pm 0.27^{\star}$ & $0.45 \pm 0.27^{*}$ & 0.01 \\
\hline Year 5 & $0.61 \pm 0.29^{\star}$ & $0.41 \pm 0.27^{\star}$ & $0.43 \pm 0.28^{\star}$ & 0.01 \\
\hline \multicolumn{5}{|c|}{ Mean best corrected visual acuity } \\
\hline Before treatment & $0.9 \pm 0.13$ & $0.86 \pm 0.15$ & $0.87 \pm 0.14$ & 0.53 \\
\hline 3 months & $0.95 \pm 0.1^{*}$ & $0.85 \pm 0.16$ & $0.85 \pm 0.14^{*}$ & 0.007 \\
\hline 6 months & $0.95 \pm 0.1^{*}$ & $0.85 \pm 0.16$ & $0.85 \pm 0.14^{*}$ & 0.007 \\
\hline Year 1 & $0.95 \pm 0.1^{*}$ & $0.83 \pm 0.17^{\star}$ & $0.83 \pm 0.17^{*}$ & 0.001 \\
\hline Year 2 & $0.95 \pm 0.1^{*}$ & $0.81 \pm 0.18^{*}$ & $0.8 \pm 0.17^{*}$ & 0.000 \\
\hline Year 3 & $0.94 \pm 0.1^{*}$ & $0.78 \pm 0.19^{*}$ & $0.75 \pm 0.2^{*}$ & 0.000 \\
\hline Year 4 & $0.94 \pm 0.1^{*}$ & $0.76 \pm 0.19^{*}$ & $0.7 \pm 0.23^{\star}$ & 0.000 \\
\hline Year 5 & $0.94 \pm 0.1^{*}$ & $0.73 \pm 0.21^{\star}$ & $0.68 \pm 0.24^{*}$ & 0.000 \\
\hline \multicolumn{5}{|c|}{ Mean central retinal sensitivity } \\
\hline Before treatment & $26.3 \pm 1.65$ & $26.3 \pm 1.57$ & $27.1 \pm 1.52$ & 0.13 \\
\hline 3 months & $27.0 \pm 1.5^{\star}$ & $26.6 \pm 1.68$ & $26.8 \pm 1.56^{\star}$ & 0.61 \\
\hline 6 months & $27.1 \pm 1.5^{\star}$ & $26.5 \pm 1.73$ & $26.6 \pm 1.62^{\star}$ & 0.51 \\
\hline Year 1 & $27.1 \pm 1.5^{\star}$ & $26.2 \pm 1.5$ & $26.2 \pm 1.68^{*}$ & 0.06 \\
\hline Year 2 & $27.1 \pm 1.5^{\star}$ & $25.9 \pm 1.52^{*}$ & $26 \pm 1.68^{*}$ & 0.01 \\
\hline Year 3 & $27.1 \pm 1.5^{*}$ & $25.7 \pm 1.69^{*}$ & $25.7 \pm 1.78^{*}$ & 0.002 \\
\hline Year 4 & $27.1 \pm 1.5^{\star}$ & $25.6 \pm 1.71^{*}$ & $25.5 \pm 1.92^{*}$ & 0.000 \\
\hline Year 5 & $27.1 \pm 1.5^{\star}$ & $25.5 \pm 1.79^{\star}$ & $25.4 \pm 1.88^{*}$ & 0.000 \\
\hline \multicolumn{5}{|c|}{ Mean central retinal thickness } \\
\hline Before treatment & $282.8 \pm 27.1$ & $292.4 \pm 62.2$ & $301.4 \pm 44.8$ & 0.37 \\
\hline 3 months & $277.6 \pm 42.9$ & $291.7 \pm 63.6$ & $308.8 \pm 45.1^{*}$ & 0.06 \\
\hline 6 months & $277.5 \pm 42.5$ & $293.6 \pm 64.6$ & $316.6 \pm 43.2^{*}$ & 0.01 \\
\hline Year 1 & $277.7 \pm 44.4$ & $300 \pm 65.6^{*}$ & $323.6 \pm 43.6^{*}$ & 0.003 \\
\hline Year 2 & $277.1 \pm 41.5$ & $303.9 \pm 65.1^{*}$ & $331.5 \pm 49^{*}$ & 0.000 \\
\hline Year 3 & $274.9 \pm 41.2^{*}$ & $304 \pm 63.9^{*}$ & $338.1 \pm 48.1^{*}$ & 0.000 \\
\hline Year 4 & $274.9 \pm 41.8^{*}$ & $306.5 \pm 63.4^{*}$ & $345.9 \pm 48.1^{\star}$ & 0.000 \\
\hline Year 5 & $275.1 \pm 42.2^{*}$ & $309.7 \pm 63.2^{*}$ & $349.7 \pm 49.1^{*}$ & 0.000 \\
\hline
\end{tabular}

Note: ${ }^{*}-$ significant difference from benchmark data, paired sample $t$-test $(p<0.05)$, ANOVA $(p<0.05)$. 


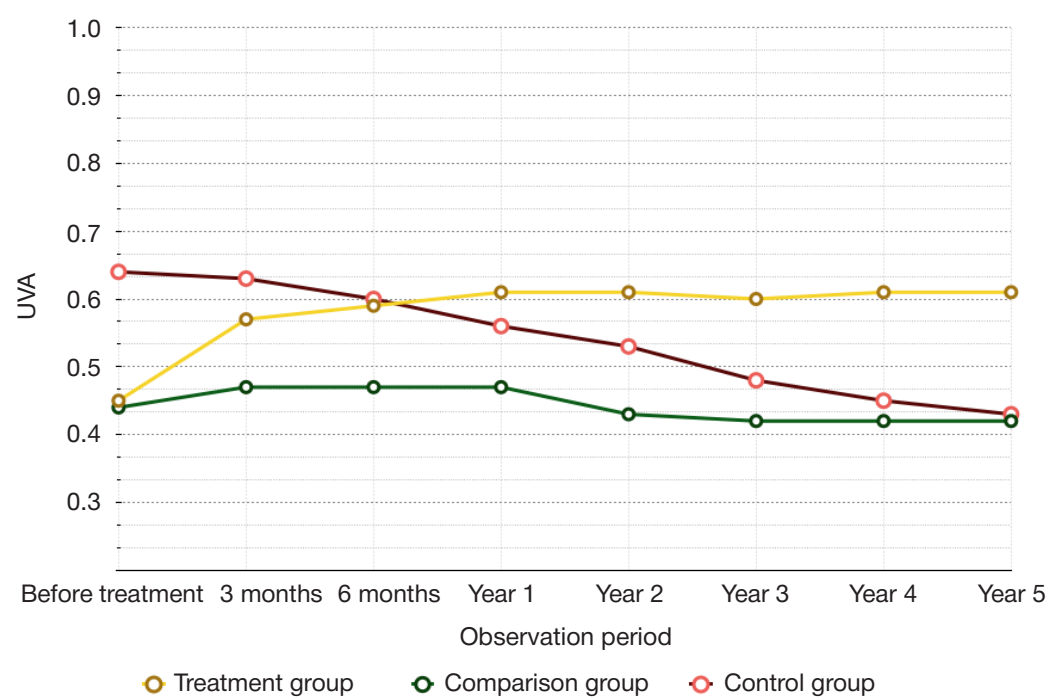

Fig. 1. Mean UVA dynamics, all groups. Treatment group - yellow line; UVA increased significantly from the 3rd to the 12th month of observation, results persisted throughout the observation period. Comparison group - green line; mean UVA was increasing significantly up to the 3rd month, from the 6th month onward to the end of the observation period the indicators were decreasing significantly. Control group — red line; mean UVA was falling significantly throughout the observation period

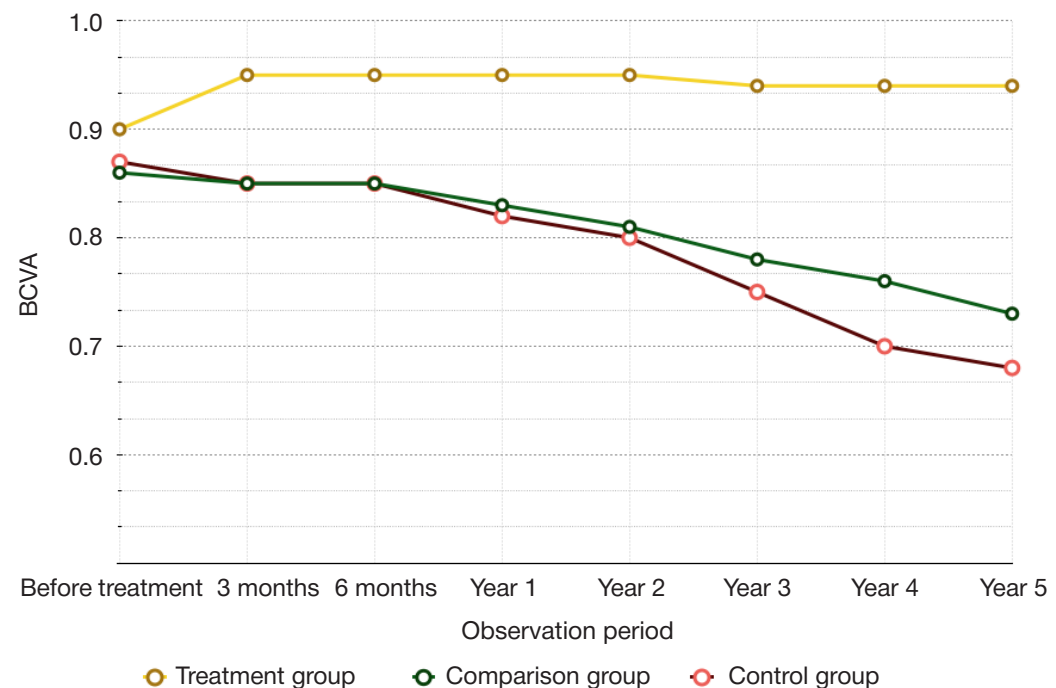

Fig. 2. Mean BCVA dynamics, all groups. Treatment group - yellow line; BCVA increased significantly from the 3rd to the 12th month of observation, results persisted throughout the observation period. Comparison group - green line; within the first 3 months of observation, mean BCVA changes were insignificant, but from the 12 th month on this indicator was decreasing gradually, the difference being significant. Control group — red line; mean BCVA was falling significantly throughout the observation period

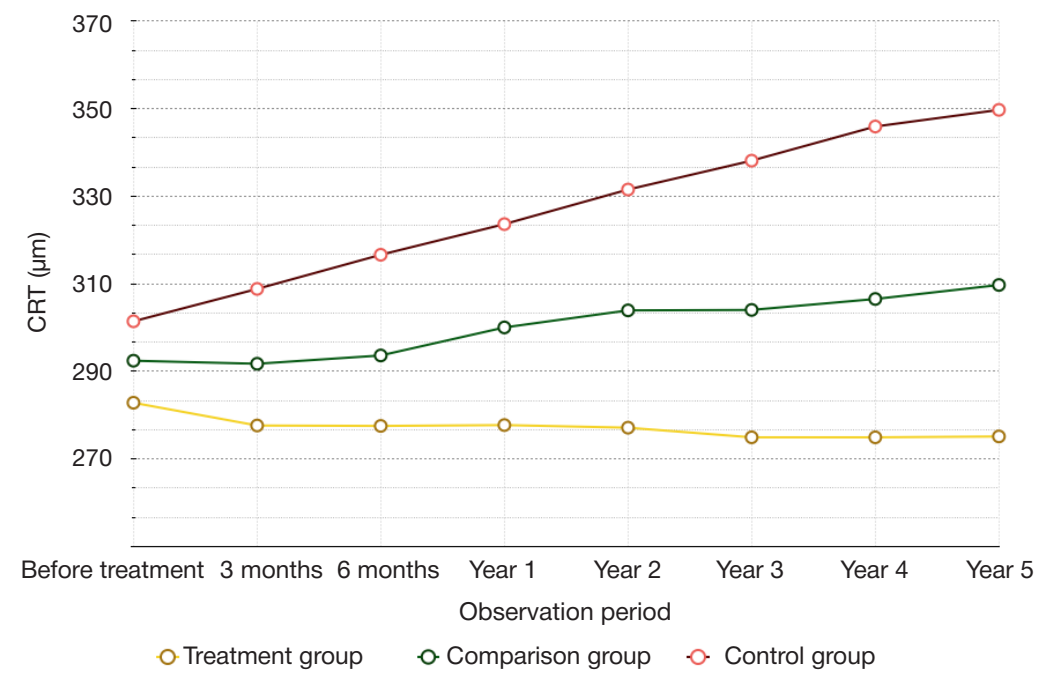

Fig. 3. Mean CRT dynamics, all groups. Treatment group - yellow line; the analysis of mean CRT did not reveal significant differences from the benchmark data within the first 6 months, but from the 12th month on, this indicator was increasing significantly. Comparison group - green line; the analysis of mean CRT did not reveal significant differences from the benchmark data within the first 6 months, but from the 12th month on, this indicator was increasing significantly. Control group - red line; mean CRT was increasing significantly from the 3rd month on to the end of the observation period 


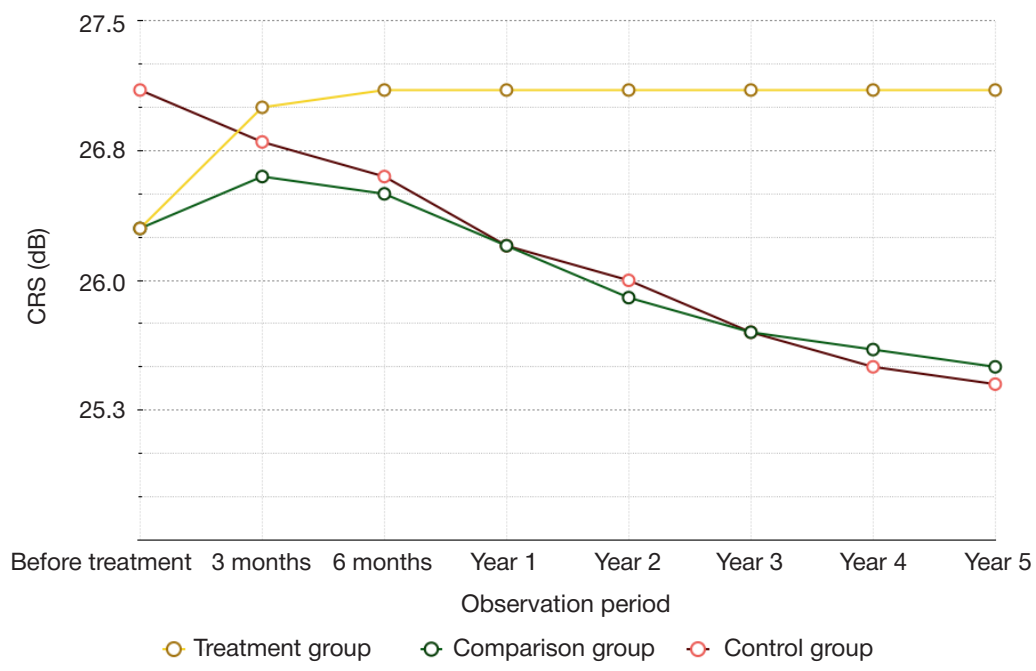

Fig. 4. Mean CRS dynamics, all groups. Treatment group - yellow line; mean CRS increased significantly from the 3rd to the 12th month of observation, results persisted throughout the observation period. Comparison group - green line; within the first 12 months of observation, mean CRS changes were insignificant, but from the 2 nd to the 5 th year of observation the indicator decreased significantly. Control group — red line; mean CRS was decreasing significantly from the 3rd month on to the end of the observation period

Table 2 presents analysis of clinical and functional results of treatment and dynamic observation of patients with idiopathic ERM.

In the control group, mean UVA and BCVA were decreasing significantly throughout the observation period (Fig. 1, 2). According to the OCT data, mean CRT was increasing significantly from the 3rd month on (Fig. 3), while mean CRS, on the contrary, was significantly increasing from the 3rd month on (Fig. 4). Multispectral imaging revealed continued proliferation on the retinal surface (Fig. 5A, B).

In the comparison group, the mean UVA was increasing significantly up to the 3rd month and decreasing from the 6th month on (Fig. 1). Within the first 3 months of observation, mean BCVA changes were insignificant, but from the 12th month on this indicator was decreasing gradually, the difference being significant (Fig. 2). The analysis of mean CRT did not reveal significant differences from the benchmark data within the first 6 months, but from the 12th month on, this indicator
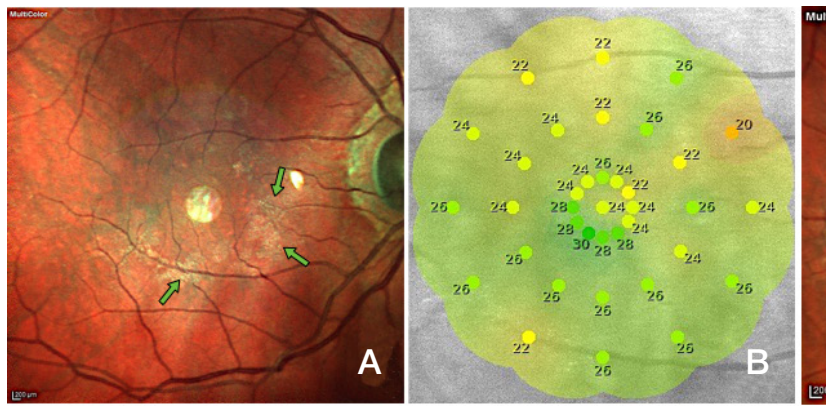

was increasing significantly (Fig. 3) and ERM was developing (Fig. 6A, B). Computer microperimetry did not register significant changes of mean CRS within the first 12 months, but from the 2nd to the 5th years it was decreasing, and these changes were significant (Fig. 4).

Comparing the results registered in treatment, comparison and control groups we established that only patients of the treatment group enjoyed significant improvement of visual and functional indicators (UVA, BCVA and CRS) combined with decreasing CRT and idiopathic ERM involution, these results staying stable throughout observation (Fig. 7A, B). In the comparison group, the indicators improved for a short period of time (up to the 3rd month), and then began to gradually deteriorate; in the control group, such deterioration, significant, was registered at all observation timepoints (Fig. 1-4).

Laser treatment did not inflict biomechanical damage to the retina in treatment and comparison groups, as confirmed by the results of computer microperimetry and SOCT.

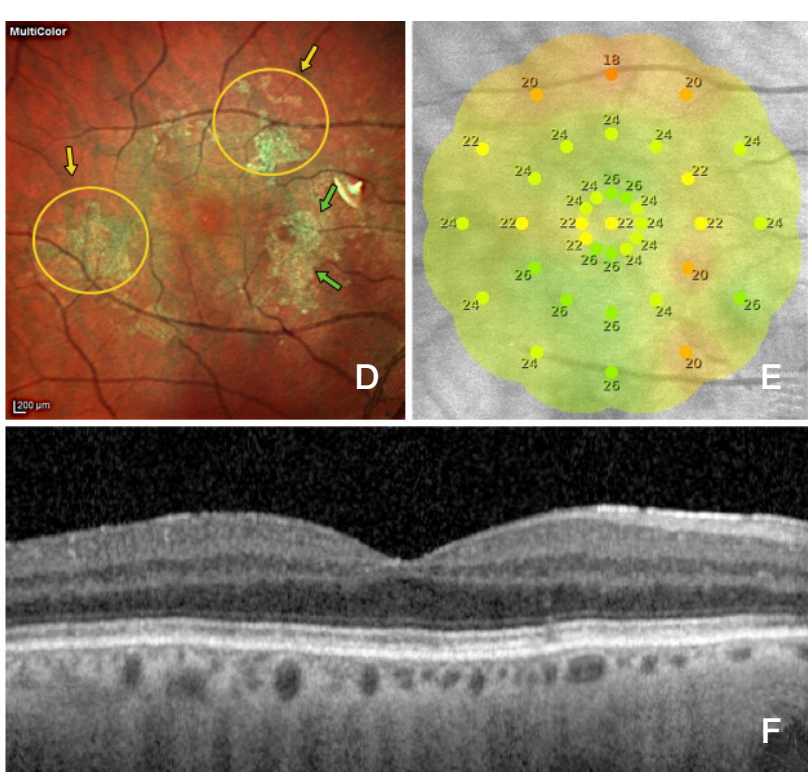

Fig. 5. Control group. Patient E, 58 years old. Results of the initial examinations: ERM surface and boundaries visualized yellow-green through multispectral imaging (Multicolor) (A); mean CRS (computer microperimetry data) - $24.9 \mathrm{~dB}$ (B); SOCT revealed a hyperreflective line on the ILM surface corresponding to the ERM, foveal pit morphology preserved $(\mathbf{C})$. Results of examinations at the end of the 1st year of observation: multispectral imaging showed continued proliferation of ERM with new foci (yellow arrow) and continued growth of the fibrosis area (green arrow) (D); Mean CRS - $23.5 \mathrm{~dB}$ (E); SOCT revealed persistence of ERM on the ILM surface, foveal pit morphology preserved (F) 

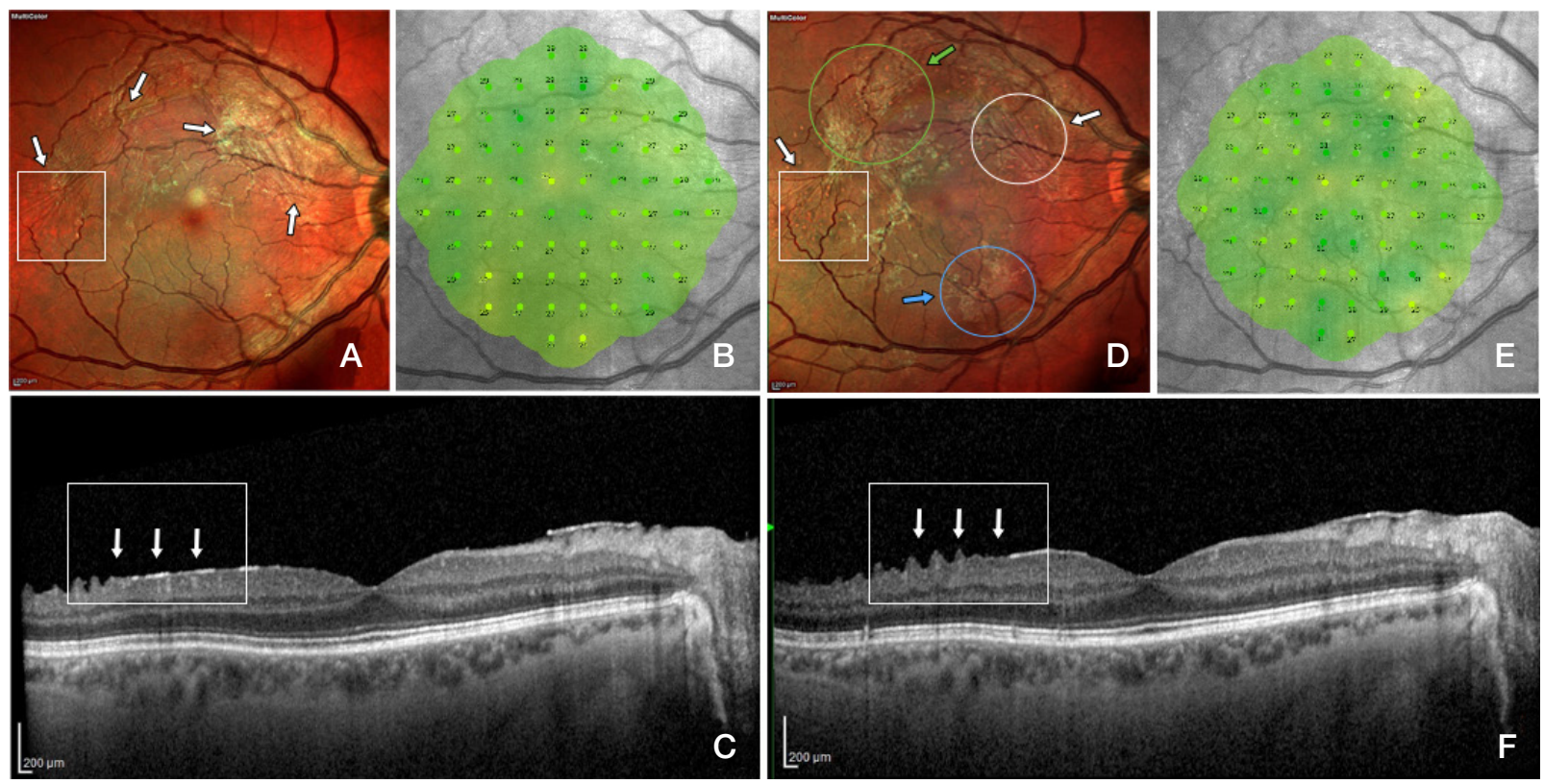

Fig. 6. Comparison group. Patient S., 56 years old. Results of the initial examinations: ERM surface and boundaries visualized yellow-green through multispectral imaging (Multicolor; white arrow) (A); mean CRS (computer microperimetry data) - $28.2 \mathrm{~dB}$ (B); SOCT revealed a hyperreflective line on the ILM surface corresponding to the ERM (white arrow), foveal pit morphology preserved, CRT - $239 \mu \mathrm{m}$ (C). Results of examinations at the end of the 2 nd year of observation: multispectral imaging showed laser coagulates and the resulting ERM involution spots (white arrow), ERM activation spots (green arrow) and new fibrosis foci (blue arrow) (D); mean CRS $27.8 \mathrm{~dB}(\mathrm{E}) ;$ SOCT revealed an almost complete absence of hyperreflective line (ERM) (white arrow), corresponding to the Multicolor visualized zone (white rectangle), foveal pit morphology preserved, CRT - $237 \mu \mathrm{m}(\mathbf{F})$
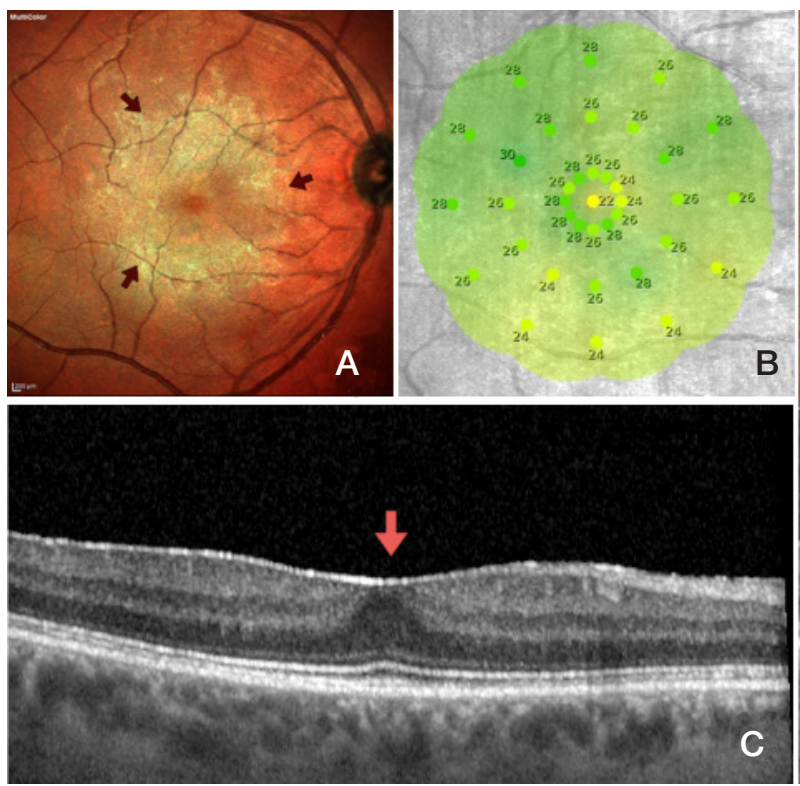

B

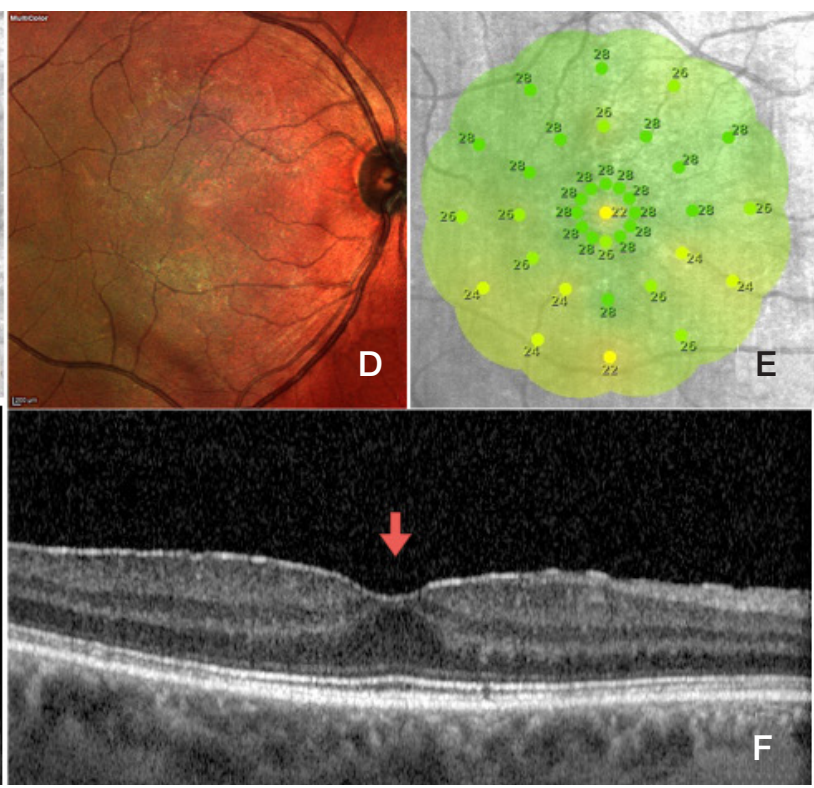

Fig. 7. Treatment group, Patient I, 68 years old. Results of the initial examinations: ERM surface and boundaries visualized yellow-green through multispectral imaging (Multicolor; red arrow) (A); mean CRS (computer microperimetry data) - $26.3 \mathrm{~dB}(\mathbf{B})$; SOCT revealed a hyperreflective line on the ILM surface corresponding to the ERM, foveal pit morphology flat (red arrow), CRT $-257 \mu \mathrm{m}(\mathbf{C})$. Results of examinations at the end of the 5th year of observation: multispectral imaging showed total involution of ERM (D); mean CRS - $26.6 \mathrm{~dB}(\mathrm{E})$; SOCT revealed a less "solid" hyperreflective line (ERM) and forming foveal pit morphology (red arrow), CRT — 234 um (F)

\section{CONCLUSIONS}

Assessed against the results registered in comparison and control groups, the suggested combined laser treatment technique applied in the treatment group proved to be highly effective in maintaining/improving visual functional indicators and stabilizing/improving morphofunctional indicators throughout the entire period of observation. As for the morphological and functional structures of sensory retina, the combined laser treatment technique is a safe option, which is proved by the retinal sensitivity improvements registered at the different timepoints of the observation period. 


\section{References}

1. Balashova LM, Zaǐceva NS, Saksonova EO i dr. Patogeneticheskie faktory razvitiya proliferativnoǏ vitreoretinopatii pri distroficheskor otsloike setchatki. Proliferativny̌̌ sindrom v oftal'mologii. 2000; (1): 12-3.

2. Campochiaro PA. Pathogenic mechanisms in proliferative vitreoretinopathy. Archives of ophthalmology. 1997; 115 (2): 407-8.

3. Pastor JC. Proliferative vitreoretinopathy: an overview. Survey of Ophthalmology. 1998; 43 (1): 3-18.

4. Kachalina GF, Doga AV, Kasmynina TA, Kuranova OI. Epiretinal'nyi fibroz: patogenez, iskhody, sposoby lecheniya. Oftal'mohirurgiya. 2013; (4): 108-10.

5. Zaharov VD, Borzenok SA, Gorshkom IM, Kolesnik SV, Kolesnik AI, Miridonova AV. Etiopatogeneticheskie aspekty i rol' struktur vitreoretinal'nogo interfejsa v formirovanii idiopaticheskih epiretinal'nyh membran. Prakticheskaya medicina. 2018; 114 (3): 71-6.

6. Ponomeryova EN, Kazaryan AA. Strukturno-funkcional'nye osobennosti makulyarnoj zony setchatki pri idiopaticheskoj epiretinal'noj membrane. Rossijskij oftal'mologicheskij zhurnal. 2013; 6 (2): 66-9.

7. Guidry C. The role of Muller cells in fibrocontractive retinal disorders. Progress in Retinal and Eye Research. 2005; 24 (1): 75-86.

8. Harada C, Mitamura Y, Harada T. The role of cytokines and trophic factors in epiretinal membranes: Involvement of signal transduction in glial cells. Progress in Retinal and Eye Research. 2006; 25 (2): 149-64.

9. Zhao F, Gandorfer A, Haritoglou C. Epiretinal cell proliferation in macular pucker and vitreomacular traction syndrome: analysis of flat-mounted internal limiting membrane specimens. Retina. 2013; 33 (1): 77-88.

10. Joshi M, Agrawal S, Christoforidis JB. Inflammatory mechanisms of idiopathic epiretinal membrane formation. Mediators Inflammation. 2013; DOI: 10.1155/2013/192582.

11. Speca S, Giusti I, Rieder F, Latella G. Cellular and molecular mechanisms of intestinal fibrosis. World Journal of Gastroenterology. 2012; 18 (28): 3635-61.

12. Shurygina IA i dr. Fibroblasty I ih rol' $\mathrm{v}$ razvitii soedinitel'noj tkani. SibirskiI medicinskii zhurnal. 2012; 110 (3): 8-12.

13. Hinz B, Gabbiani G. Fibrosis: recent advances in myofibroblast biology and new therapeutic perspectives. Molecular Biology Reports. 2010; (2): 78.

14. Gass JDM. Macular dysfunction caused by epiretinal membrane contraction. In: Stereoscopic Atlas of Macular Diseases: Diagnosis and Treatment. 1997; 2 (4): 938-50.

15. Kuranova Ol. Izuchenie effektivnosti mikroimpul'snogo lazernogo vozdejstviya dlinoj volny $577 \mathrm{~nm}$ pri makulyarnom oteke posle hirurgicheskogo udaleniya idiopaticheskoj epiretinal'noj membrany (dissertation). 2014; 33

16. Zaharov VD, Borzenok SA, Gorshkov IM, Kolesnik SV, Kolesnik AI, Kupriyanova AG, Ostrovskij DS, Miridonova AV. Klinikoeksperimental'naya ocenka rannego hirurgicheskogo lecheniya idiopaticheskih epiretinal'nyh membran u pacientov s nachal'nymi priznakami patologicheskogo processa. Sovremennye tekhnologii v oftal'mologii. 2018; 21 (1): 127-30.

17. Pichi $F$, Lembo A, Morara M, Veronese $C$, Alkabes M, Nucci $P$, Ciardella A. Early and late inner retinal changes after inner limiting membrane peeling. International Ophthalmology. 2013; 34 (2): 437-46.

18. Mazit C, Scholtes F. Assessment of macular profile using optical coherens tomography after epiretinal membrane surgery. Journal Français D'Ophtalmologie. 2008; 31 (7): 667-72.

19. Bu S, Kuijer R, Li X, Hooymans J, Los L. Idiopathic epiretinal membrane. Retina. 2014; 34 (12): 2317-35.

20. Tahchidi HP, Kachalina GF, Kasmynina TA, Tebina EP. Sposob kombinirovannogo lazernogo lecheniya nachal'noj stadii epiretinal'nogo fibroza. Russian Federation Patent RF № 2634684. 02.11.2017.

\section{Литература}

1. Балашова Л. М., Зайцева Н. С., Саксонова Е. О. и др. Патогенетические факторы развития пролиферативной витреоретинопатии при дистрофической отслойке сетчатки. Пролиферативный синдром в офтальмологии. 2000; (1): 12-3.

2. Campochiaro PA. Pathogenic mechanisms in proliferative vitreoretinopathy. Archives of ophthalmology. 1997; 115 (2): 407-8.

3. Pastor JC. Proliferative vitreoretinopathy: an overview. Survey of Ophthalmology. 1998; 43 (1): 3-18.

4. Качалина Г. Ф., Дога А. В., Касмынина Т. А., Куранова О. И. Эпиретинальный фиброз: патогенез, исходы, способы лечения. Офртальмохирургия. 2013; (4): 108-10.

5. Захаров В. Д., Борзенок С. А., Горшком И. М., Колесник С. В., Колесник А. И., Миридонова А. В. Этиопатогенетические аспекты и роль структур витреоретинального интерфейса в формировании идиопатических эпиретинальных мембран. Практическая медицина. 2018; 114 (3): 71-6.

6. Пономерёва Е. Н., Казарян А. А. Структурно-фуннцциональные особенности макулярной зоны сетчатки при идиопатической эпиретинальной мембране. Российский офтальмологический журнал. 2013; 6 (2): 66-9.

7. Guidry C. The role of Muller cells in fibrocontractive retinal disorders Progress in Retinal and Eye Research. 2005; 24 (1): 75-86.

8. Harada C, Mitamura Y, Harada T. The role of cytokines and trophic factors in epiretinal membranes: Involvement of signal transduction in glial cells. Progress in Retinal and Eye Research. 2006; 25 (2): 149-64.

9. Zhao F, Gandorfer A, Haritoglou C. Epiretinal cell proliferation in macular pucker and vitreomacular traction syndrome: analysis of flat-mounted internal limiting membrane specimens. Retina. 2013; 33 (1): 77-88.

10. Joshi M, Agrawal S, Christoforidis JB. Inflammatory mechanisms of idiopathic epiretinal membrane formation. Mediators Inflammation. 2013; DOI: 10.1155/2013/192582.

11. Speca S, Giusti I, Rieder F, Latella G. Cellular and molecular

mechanisms of intestinal fibrosis. World Journal of Gastroenterology. 2012; 18 (28): 3635-61.

12. Шурыгина И. А. и др. Фибробласты и их роль в развитии соединительной ткани. Сибирский медицинский журнал (Иркутск). 2012; 110 (3): 8-12.

13. Hinz B, Gabbiani G. Fibrosis: recent advances in myofibroblast biology and new therapeutic perspectives. Molecular Biology Reports. 2010; (2): 78.

14. Gass JDM. Macular dysfunction caused by epiretinal membrane contraction. In: Stereoscopic Atlas of Macular Diseases: Diagnosis and Treatment. 1997; 2 (4): 938-50.

15. Куранова О. И. Изучение эфффективности микроимпульсного лазерного воздействия длиной волны 577 нм при макулярном отеке после хирургического удаления идиопатической эпиретинальной мембраны (диссертация). 2014; 33.

16. Захаров В. Д., Борзенок С. А., Горшков И. М., Колесник С. В., Колесник А. И., Куприянова А. Г., Островский Д. С., Миридонова А. В. Клинико-экспериментальная оценка раннего хирургического лечения идиопатических эпиретинальных мембран у пациентов с начальными признаками патологического процесса. Современные технологиив офтальмологии. 2018; 21 (1): 127-30.

17. Pichi F, Lembo A, Morara M, Veronese C, Alkabes M, Nucci P, Ciardella A. Early and late inner retinal changes after inner limiting membrane peeling. International Ophthalmology. 2013; 34 (2): 437-46.

18. Mazit C, Scholtes F. Assessment of macular profile using optical coherens tomography after epiretinal membrane surgery. Journal Français D'Ophtalmologie. 2008; 31 (7): 667-72.

19. Bu S, Kuijer R, Li X, Hooymans J, Los L. Idiopathic epiretinal membrane. Retina. 2014; 34 (12): 2317-35.

20. Тахчиди Х. П., Качалина Г. Ф., Касмынина Т. А., Тебина Е. П. Способ комбинированного лазерного лечения начальной стадии эпиретинального фиброза. Патент РФ № 2634684. 02.11.2017. 